\title{
To Join Or Not To Join? A Case Of Sickle Cell Clubs, Stigma And Discrimination In Secondary Schools In Butambala District, Uganda
}

This article was published in the following Dove Press journal:

Adolescent Health, Medicine and Therapeutics

\author{
Sharifu K Tusuubira $\mathbb{D}^{1,2}$ \\ Tracy Naggawa' \\ Victoria Nakamoga $\mathbb{D}^{\prime}$
}

'Uganda Sickle Cell Rescue Foundation, Kampala, Uganda; ${ }^{2}$ Clarke International University, Kampala, Uganda
Background: People living with sickle cell face a lot of stigma and discrimination in Uganda. This stigma is as a result of the lack of the general conceptualization of this condition. For students, the stigma is often due to their differences like jaundice, delayed sexual maturation, and physical growth. This makes individuals with SCD targets for teasing and bullying. This study assessed the knowledge and perception among secondary school students in a rural district of Butambala at nine selected schools. The study also evaluated the use of sickle cell clubs as a tool for behavior change towards the associated stigma and discrimination.

Methods: A school-based cross-sectional study design was used to assess knowledge and perception towards sickle cell disease in secondary schools in Butambala district using selfadministered questionnaires prior to and after set up of the sickle cell clubs.

Results: Out of the 375 student participants (59.5\% female, $40.5 \%$ male) the majority $(87.5 \%)$ were below 18 years; $68 \%$ of the respondents did not know that sickle cell is a genetic condition; $87.5 \%$ of the respondents highlighted that it is important for people with SCD to attend school; $54.4 \%$ of the respondents reported that people with SCD should not be given equal rights, while $56.0 \%$ of the respondents noted that people with SCD should not socialize.

Conclusion: It is evident the there is a big gap in sickle cell awareness among secondary school students coupled with a high level of stigma and discrimination. Sickle cell clubs have a positive effect towards behavior change while providing SCD knowledge and information. Keywords: stigma, discrimination, awareness, sickle cell disease, schools

\section{Introduction}

Worldwide, sickle cell disease (SCD) is the commonest inheritable blood disorder. ${ }^{1}$ It is associated with episodes of acute illness resulting from stiff and sticky red blood cells clogging tiny blood vessels. ${ }^{2,3}$

The global burden of SCD is increasing, with an estimated 14,242,000 newborns between 2010 and $2050 .^{4}$ A great proportion, $82 \%$, of these births will occur in Sub Saharan Africa. ${ }^{5}$ Uganda has the fifth highest sickle cell burden, ${ }^{6}$ with $13.3 \%$ of the population being sickle cell heterozygous carrier state $(\mathrm{HbAS}) .^{7}$ It is estimated that 15,000 to 20,000 babies are born annually with SCD in Uganda.,

SCD is linked with a lifelong risk of hospitalization, decreased life expectancy, and a poor quality of life. ${ }^{8}$ In Uganda, there are concerted efforts to address this burden from the Ministry of Health, cultural institutions (Buganda Kingdom), and 
non-governmental organizations like the Uganda Sickle Cell Rescue Foundation. These efforts are geared towards improving awareness, reducing mortality, while increasing sickle cell management and care outcomes.

Sickle cell management and care outcomes are complicated by the interaction of SCD patients with the socioecological system. ${ }^{9-11}$ SCD patients often experience numerous physical and psychosocial complications. ${ }^{12}$ In Uganda, this situation is worsened by inaccessible formal social support structures to aid families and patients to cope better with the associated psychosocial burden. ${ }^{6}$

As children with SCD mature into adolescence, they face several challenges in addition to the typical adolescent challenges. These children have been observed to have a deterioration in physical, social, and emotional functioning which affects their self-esteem. ${ }^{13}$ The adolescents with SCD also have more frequent hospitalizations, and a longer length of stay. ${ }^{14-16}$ SCD associated challenges like nonattendance of school, lower academic performance (at times), and delayed sexual maturation and physical growth ${ }^{17-19}$ often make individuals with SCD targets for teasing and bullying.

Individuals with SCD in resource limited settings like Uganda face many impediments while receiving an education, but stigma is one of most powerful and threatening. According to one person living with SCD, "I was often discriminated in school; none of my fellow students would want to share utensils with me Keep Smart". ${ }^{20}$ For schoolgoing children with SCD, the attitude of classmates is vital, as stigmatizing attitudes can lead to peer rejection. Peer rejection is associated with emotional distress, academic underachievement, school avoidance, and long-term occupational failure in adulthood. ${ }^{21}$ This study therefore set out to assess the knowledge and perception of secondary students towards sickle cell disease before the creation of sickle cell clubs in the select schools. This study later evaluated the student's experiences 4 months after creation of sickle cell clubs. This work was part of the school outreach initiative run by the Uganda Sickle Cell Rescue Foundation. This information is crucial in understanding stigma in secondary schools in order to make schools positive and safe for adolescents and young adults living with sickle cell disease. In addition, this work is key in drawing attention to potential areas for intervention and improvement to foster better outcomes in sickle cell prevention, awareness, and management. This will contribute to building an inclusive, educated, and empowered population of young people in Uganda.

\section{Methods}

A school-based cross-sectional study design was employed to assess knowledge and perception towards sickle cell disease in secondary schools in Butambala district using self-administered questionnaires prior to set up of the sickle cell clubs. The questionnaire was distributed after a detailed explanation on how to fill it. After 4 months, student's experiences from the sickle cell clubs were evaluated using an interviewer administered questionnaire.

\section{Study Area}

The study was carried out in Butambala district, rural area located in central Uganda.

\section{Sample Size And Sampling Technique}

The survey considered a sample size of 375 participants, who were obtained using the formula by Kish Leslie (1965) for cross-sectional studies. ${ }^{22}$ A 95\% level of confidence, $50 \%$ proportion was estimated and a $5 \%$ level of confidence were used in the sample calculation. Random sampling was used to select eligible participants. Eligible participants for the knowledge and perception survey were students who have studied in the select schools for more than two terms. Eligible participants for the sickle cell club experience survey were club members who have attended two or more sickle cell club meetings.

\section{Statistical Analysis Plan}

The data were analyzed using descriptive statistics in SPSS version 17.

\section{Sickle Cell Clubs}

Uganda Sickle Cell Rescue Foundation (USCRF) works to promote sickle cell awareness while advocating against the associated stigma. USCRF initiated a project of sickle cell clubs in schools for the promotion of behavior change towards associated stigma and discrimination. This sickle cell club project is based on the assumption that existing sickle cell awareness initiatives can be strengthened for greater impact by providing education, counselling, and technical assistance within a school setting. The clubs target youth aged 10-25 years in mostly secondary schools towards promoting positive attitudes for sickle cell and SCD patients. Butambala district served as a pilot area for this club initiative. 


\section{Results}

\section{Characteristics Of Respondents}

From Table 1 it can be seen that more than half of the respondents $(59.5 \%)$ were female, the majority $(87.5 \%)$

Table I Characteristics Of Respondents

\begin{tabular}{|l|l|l|}
\hline \multicolumn{2}{|l|}{ Demographics Characteristics Of The Respondents } \\
\hline Variable & Frequency (N=375) & Percentage \\
\hline Sex & & \\
Male & 149 & 39.7 \\
Female & 226 & 59.5 \\
\hline Age (years) & 44 & 16.9 \\
<18 & 328 & 87.5 \\
I8-25 & 42 & 11.2 \\
$>25$ & 5 & 1.3 \\
\hline Class & & \\
S.I & 130 & 34.7 \\
S.2 & 89 & 23.7 \\
S.3 & 64 & 17.1 \\
S.4 & 39 & 10.4 \\
S.5 & 31 & 8.3 \\
S6 & 8 & 2.1 \\
Teachers & 15 & 4.0 \\
\hline Have Sickle cell & & \\
Yes & 14 & 3.7 \\
No & 361 & 96.3 \\
\hline Tested for SCD & & \\
Yes & 338 & \\
No & & \\
\hline
\end{tabular}

were below 18 years with the highest proportion (34.7\%) of respondents in S.1. The majority (96.3\%) of the respondents did not have SCD and many of the respondents had never tested for SCD.

\section{Characteristics Of The Selected Schools}

Table 2 shows a detailed description of each of the select schools where the pilot of the sickle cell clubs was implemented.

\section{Knowledge On Sickle Cell Disease}

Table 3 shows that $68 \%$ of the respondents did not know that sickle cell is a genetic condition. The highest proportion of respondents $(44.8 \%)$ was not sure whether SCD could be transmitted through physical contact. A total of $53.3 \%$ of the respondents were not sure whether one could develop SCD over time. The highest proportion (43.2\%) of respondents were still not sure whether SCD could be inherited when both parents have the trait. The highest proportion $(37.9 \%)$ of respondents knew that you could have SC trait even if both parents have no trait, as shown in Table 3.

\section{Perception Towards SCD}

The students' perception about SCD was assessed with seven statements to which the students indicated "yes", "no", or "not sure" responses. Table 4 shows the highest proportion (59.7\%) of respondents reported that people with SCD should be employed. A total of $56.0 \%$ of the respondents noted that people with SCD should not

Table 2 School Information

\begin{tabular}{|l|l|l|l|}
\hline & Secondary School & School Description & $\begin{array}{l}\text { Location/ } \\
\text { Village }\end{array}$ \\
\hline I & $\begin{array}{l}\text { Kibibi Muslim Secondary } \\
\text { School } \\
\text { Sayidina Abubaker } \\
\text { Secondary School } \\
\text { Kibibi Parents School } \\
\text { Kaggulwe Secondary } \\
\text { School } \\
\text { Kibibi Central College } \\
\text { School }\end{array}$ & $\begin{array}{l}\text { Privately owned, admits both males and females, and has both boarding and day sections, } \\
\text { Government school, admits both males and females, it has a boarding and day section with } \\
\text { the majority of students in boarding. } \\
\text { Privately owned, admits both males and females, with a boarding and day section. }\end{array}$ & Kibibi \\
Gombe Secondary \\
5
\end{tabular}


Table 3 Knowledge On Sickle Cell Disease

\begin{tabular}{|c|c|c|}
\hline Variable & $\begin{array}{l}\text { Frequency } \\
(n=375)\end{array}$ & Percentage \\
\hline \multicolumn{3}{|l|}{ SCD is a genetic condition } \\
\hline Yes & 120 & 32.0 \\
\hline No & 50 & 13.3 \\
\hline Not sure & 205 & 54.7 \\
\hline \multicolumn{3}{|l|}{$\begin{array}{l}\text { SCD transmitted through physical } \\
\text { contact with infected person }\end{array}$} \\
\hline Yes & 55 & 14.7 \\
\hline No & 152 & 40.5 \\
\hline Not sure & 168 & 44.8 \\
\hline \multicolumn{3}{|l|}{ Can develop SCD over time } \\
\hline Yes & 98 & 26.1 \\
\hline No & 77 & 20.5 \\
\hline Not sure & 200 & 53.3 \\
\hline \multicolumn{3}{|l|}{$\begin{array}{l}\text { SCD can be inherited when both } \\
\text { parents have trait }\end{array}$} \\
\hline Yes & 138 & 36.8 \\
\hline No & 75 & 20.0 \\
\hline Not sure & 162 & 43.2 \\
\hline \multicolumn{3}{|l|}{$\begin{array}{l}\text { You can have SC trait even if both } \\
\text { parents have no trait }\end{array}$} \\
\hline Yes & 142 & 37.9 \\
\hline No & 99 & 26.4 \\
\hline Not sure & 134 & 35.7 \\
\hline
\end{tabular}

socialize. The highest proportion $(46.7 \%)$ of respondents noted that SCD is not a shameful disease. In regards to whether people with SCD die at a certain stage, the highest proportion $(42.4 \%)$ was not sure. The vast majority $(87.5 \%)$ of the respondents noted that it is important for people with SCD to attend school. The vast majority $(93.9 \%)$ of the respondents acknowledged that people with SCD should get special treatment. More than half $(54.4 \%)$ of the respondents reported that people with SCD should not be given equal rights, as shown in Table 4.

\section{Evaluation Of Sickle Cell Clubs And Students' Experiences}

The study evaluated the sickle cell clubs through questionnaires answered by select club members. They revealed the number of club meetings held in two school terms or between the surveys, as shown in Table 5 .

For student's experiences, students were asked to share how they feel about the clubs, their perception of club importance, and expectations from the clubs. Students who
Table 4 Perception Towards SCD

\begin{tabular}{|l|l|l|}
\hline Variable & Frequency & Percentage \\
\hline $\begin{array}{l}\text { Should people with SCD be employed } \\
\text { Yes }\end{array}$ & 224 & \\
No & 64 & 59.7 \\
Not sure & 89 & 17.1 \\
\hline People with SCD should not socialize & & 23.7 \\
Yes & 62 & \\
No & 210 & 16.5 \\
Not sure & 103 & 56.0 \\
\hline SCD is a shameful disease & & 27.5 \\
Yes & 86 & \\
No & 175 & 22.9 \\
Not sure & 114 & 46.7 \\
\hline People with SCD die at certain age & & 30.4 \\
Yes & 141 & 37.6 \\
No & 75 & 20.0 \\
Not sure & 159 & 42.4 \\
\hline Important for people with SCD to & & \\
attend school & & \\
Yes & 328 & 87.5 \\
No & 47 & 12.5 \\
\hline Should people with SCD get special & & \\
treatment & 204 & \\
Yes & 352 & \\
No & 23 & \\
\hline Should people with SCD be given & & \\
equal rights & & \\
Yes & & \\
\hline
\end{tabular}

identified as living with sickle cell $(n=14)$ shared their experiences as well. Table 6 shows selected responses.

\section{Discussion}

This study presents the first evaluation of how sickle cell clubs can be used in the fight against sickle associated stigma in schools. This survey further provides an understanding of how Ugandan students comprehend and perceive SCD.

As shown in the study; for knowledge, $68 \%$ of the respondents did not know that sickle cell is a genetic condition, while $37.9 \%$ of respondents knew that you could have SC trait even if both parents have no trait. For perception; $56.0 \%$ of the respondents noted that people with SCD should not socialize, while $54.4 \%$ of the respondents reported that people with SCD should not be given equal rights. Students gave a good evaluation of the 
Table 5 Number Of Club Meetings Held At Each School

\begin{tabular}{|l|l|l|l|}
\hline School & Number Of Meetings & School & Number Of Meetings \\
\hline Lukalu Secondary School & 5 & Kibibi Central college & 5 \\
Kaggulwe Secondary School & 3 & Sayidinah Abubakar Secondary School & 5 \\
Kibibi Secondary School & 3 & Gombe Secondary School & 2 \\
Kibibi Muslim Secondary School & 2 & Kawami Secondary School & 2 \\
Kibibi Parents School & 2 & & \\
\hline
\end{tabular}

Table 6 Evaluation Of Sickle Cell Clubs And Students' Experiences

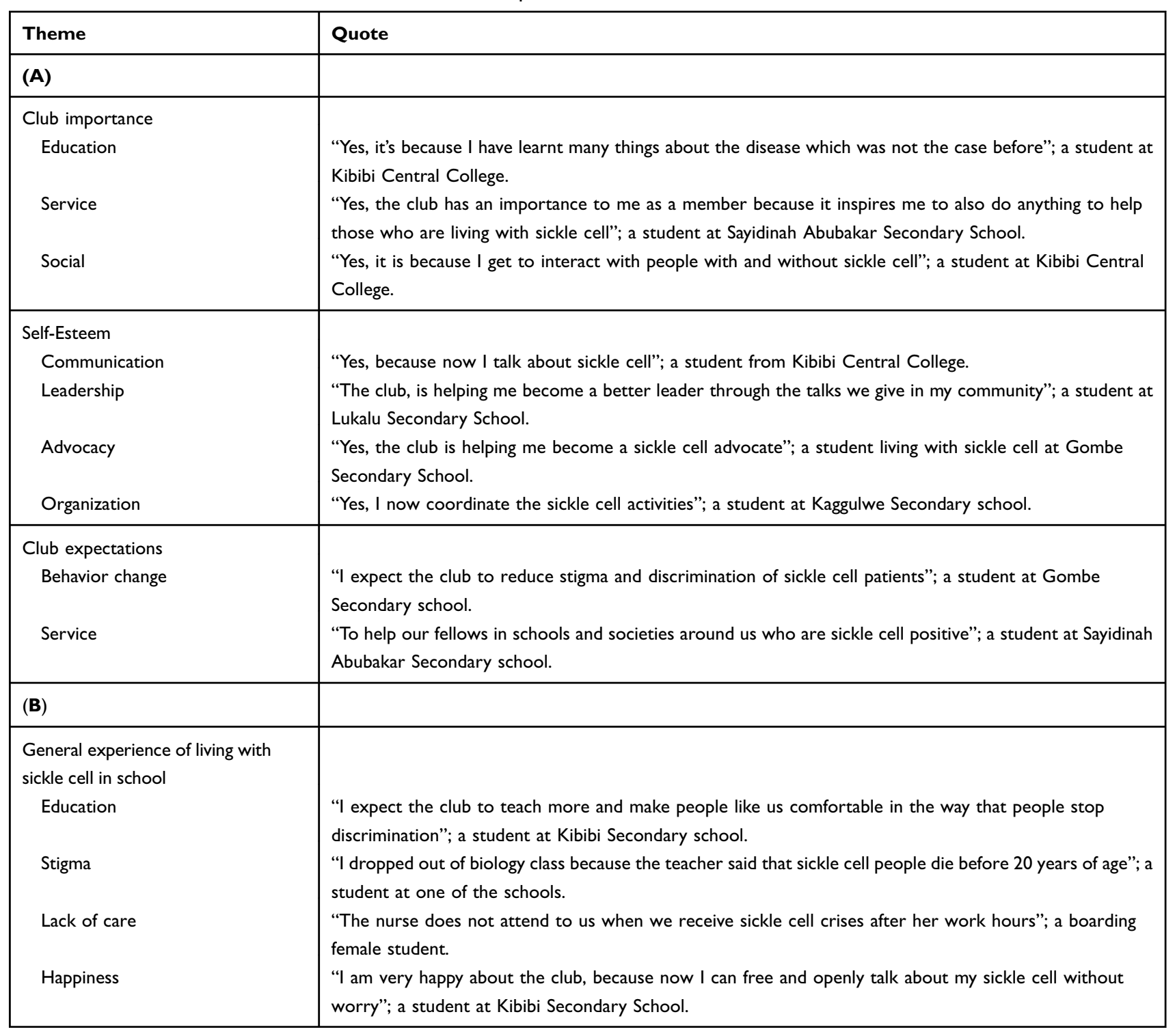

clubs highlighting important roles in building esteem among members, providing social, service, and educational roles. Students living with sickle cell highlighted the stigma and lack of appropriate care in the school settings.
More than half of the respondents (59.5\%) were female; this could be attributed to the high proportion of females in this district. ${ }^{23}$ In addition, this could be related to the health seeking behavior often exhibited by females. ${ }^{24}$ In a school setting, this could be related to the flexibility of girls to 
socialize and participate in social events. The majority of the participants $(87.5 \%)$ were 18 years and below, this is in agreement with the school going age for secondary school in Uganda, ie, lower secondary ("O" level) 13-16 years and upper secondary ("A" level) $17-18$ years. ${ }^{25}$ The highest proportion of $96.3 \%$ of the students did not have sickle cell disease, this may be due to low prevalence of sickle trait in the area. ${ }^{7}$ This could also be attributed to a lack of awareness of the disease ${ }^{26}$ and of the lack of priority in taking a sickle cell test. ${ }^{20}$

The participants knowledge towards SCD was generally lacking, demonstrating a big gap among students, this might be associated to the lack of awareness and stigma associated with the disease. ${ }^{6,20,27}$ In addition, located in Buganda kingdom this district is mostly inhabited by Baganda who have not had a local name for sickle cell until 2017 through the advocacy initiative of the Uganda Sickle Cell Rescue Foundation. This initiative gave birth to the name "Nalubiri" in the local dialect, this literally means "small bodied". The absence of a name in the local dialect further demonstrates the stigma and discrimination associated with sickle cell in this community. As evidenced through some families hiding their sick for the fear of being ostracized in society. ${ }^{20}$

For perception towards SCD, $93.9 \%$ of the participants acknowledged that people with sickle cell disease should get special treatment. This might have been due to the complexity of managing the condition or the lack of knowledge regarding this disease. In regards to school attendance, $87.5 \%$ of the participants believed that people with sickle cell disease should attend school. This is a key step in supporting students with sickle cell while in school. ${ }^{28}$ This also provides a good platform to students to support their fellow students affected by SCD. Sadly, the greatest proportion $(54.4 \%)$ of the respondents indicated that people living with sickle cell should not be given equal rights, and $56.0 \%$ noted that people with SCD should not socialize. This is a clear display of stigma and discrimination exhibited by these secondary school students. This is in agreement to Bazuaye and Olayemi ${ }^{26}$, who indicated that secondary students stigmatize those living with sickle cell. This further indicates a bigger problem in Ugandan communities where people living with sickle cell do not have rights to independent thinking, to participate freely in community activities or further agency, and enjoy the same privileges like the "normal" people. $^{20}$
For sickle cell clubs, the majority of the respondents linked the sickle cell awareness clubs to a degree of importance. The students also felt that the clubs are contributing to their continued learning and engagement. This is similar to other studies that have shown a similar positive effect associated with HIV/AIDS school clubs. ${ }^{29,30}$ This concept of sickle cell awareness clubs is built on the model of peer education for behavior and attitude change among students. ${ }^{31}$ We believe this initiative of peer education can be employed in sickle cell awareness and advocacy against associated stigma and or discrimination.

The study findings build on the existing body of knowledge of sickle cell associated stigma among adolescents and young adults. ${ }^{13,27}$ However, the study particularly highlights a novel aspect of using a peer behavior change model to address sickle cell associated stigma and discrimination in a resource limited setting like Uganda.

The study limitations include the limited geographical coverage of the study. This study was done in one district, this geographical area could have people of different cultural beliefs as compared to the rest of the country. This affects the generalizability of the study findings. The study might also have been limited by the selection bias of students due to the self-selection for participation in sickle cell club initiative. We recommend future studies to involve more student numbers in several districts of the country so as to give a better picture of the knowledge and perception of students towards SCD. Future studies should also look at tools like mobile technologies that could be employed to support students or persons living with sickle cell in coping with associated stigma in resource limited settings.

\section{Conclusion}

From this study, it is evident the there is a big gap in sickle cell awareness among secondary school students. This study also shows a high level of stigma and discrimination in schools, as evidenced by the belief that students living with sickle cell should not have equal rights. This study indicates that sickle cell clubs have a positive effect towards behavior change while providing SCD knowledge and information.

\section{Recommendations}

There is a need for more action towards addressing sickle cell associated stigma and discrimination in schools and communities at large. There is a need to adopt and promote sickle cell clubs as a tool for promoting awareness 
and advocating against associated stigma in secondary schools in Uganda.

\section{Abbreviations}

SCD, sickle cell disease; HIV/AIDS, Human Immunodeficiency Virus infection and Acquired Immune Deficiency Syndrome.

\section{Ethics Approval And Consent To Participate}

The ethics and research committee of Clarke International University approved the study procedures. Administrative clearance was obtained from the District Education officer of Butambala district and school head teachers. Written consent was obtained from participants above 18 years of age. All participants were informed about the study and participation was voluntary. For those below 18 years, written informed consent was sought from the parents while they gave verbal assent to participate. Information provided by the participants was anonymous and was kept confidential.

\section{Availability Of Data And Materials}

The authors confirm that the data and materials from this study are available

\section{Acknowledgments}

The authors would like to thank Jamie Joyce from IDEAS for Us for technical support and guidance. The authors would like to thank Alimah Komuhangi for her assistance in the data analysis. The authors want to thank the volunteers, especially Chris Ndawula, Flavia Nakawala, Euniky Musimenta, Brian Kintu, Sam Ssendiwala, Lauben Tayebwa, and Elvis Kintu. They also would like to thank head teachers of all the schools and the sickle cell club leaders in the various schools that participated in this study. They also extend their utmost thanks to Dr Bulaimu Muwanga Kibirige, Mr Erostus Nsubuga, Dr Sikander Lalani, Stuart Mwesigwa, Hajj. Haruna Kalule Kibirige, and Sis Drolence Namirembe for their support.

\section{Author Contributions}

ST drafted the manuscript. ST, TN, and VN participated in the design of the study and data collection. ST and TN participated in the data collection. All authors contributed to data analysis, drafting or revising the article, gave final approval of the version to be published, and agree to be accountable for all aspects of the work.

\section{Disclosure}

The authors declare that they have no competing interests in this work.

\section{References}

1. Gardner R. Sickle cell disease: advances in treatment. Ochsner J. 2018;18(4):377-389. doi:10.31486/toj.18.0076

2. Centers for Disease Control and Protection (2015b) What is sickle cell disease? Available from: http://www.nhlbi.nih.gov/health/healthtopics/topics/sca/. Accessed February 2, 2019.

3. Weatherall DJ. The inherited diseases of hemoglobin are an emerging global health burden. Blood. 2010;115:4331-4336. doi:10.1182/ blood-2009-12-255992

4. Piel F, Hay S, Gupta S, Weatherall D, Williams T. Global burden of sickle cell anaemia in children under five, 2010-2050: modelling based on demographics, excess mortality, and interventions. PLoS Med. 2013;10(7):e1001484. doi:10.1371/journal.pmed.1001484

5. Tluway F, Makani J. Sickle cell disease in Africa: an overview of the integrated approach to health, research, education and advocacy in Tanzania, 2004-2016. Br J Haematol. 2017;177(6):919-929. doi:10.1111/bjh.14594

6. Tusuubira S, Nakayinga R, Mwambi B, Odda J, Kiconco S, Komuhangi A. Knowledge, perception and practices towards sickle cell disease: a community survey among adults in Lubaga division, Kampala Uganda. BMC Public Health. 2018;18:1. doi:10.1186/ s12889-018-5496-4

7. Ndeezi G, Kiyaga C, Hernandez A, et al. Burden of sickle cell trait and disease in the Uganda Sickle Surveillance Study (US3): a crosssectional study. Lancet Glob Health. 2016;4(3):e195-e200. doi:10.1016/s2214-109x(15)00288-0

8. Meier E, Miller J. Sickle cell disease in children. Drugs. 2012;1. doi:10.2165/11632890-000000000-00000

9. Haywood C Jr, Lanzkron S, Bediako S, et al. Perceived discrimination, patient trust, and adherence to medical recommendations among persons with sickle cell disease. J Gen Intern Med. 2014;29 (12):1657-1662. doi:10.1007/s11606-014-2986-7

10. Zempsky WT, Loiselle KA, McKay K, Lee BH, Hagstrom JN, Schechter NL. Do children with sickle cell disease receive disparate care for pain in the emergency department? J Emerg Med. 2010;39 (5):691-695. doi:10.1016/j.jemermed.2009.06.003

11. Todd KH, Green C, Bonham VL Jr, Haywood C Jr, Ivy E. Sickle cell disease related pain: crisis and conflict. J Pain. 2006;7(7):453-458. doi:10.1016/j.jpain.2006.05.004

12. Asnani MR. Sickle cell disease. In: Stone JH, Blouin M, editors. International Encyclopedia of Rehabilitation. Buffalo, NY: Center for International Rehabilitation Research Information and Exchange; 2010:1-20.

13. Adeyemo T, Ojewunmi O, Diaku-Akinwumi I, Ayinde O, Akanmu A. Health related quality of life and perception of stigmatisation in adolescents living with sickle cell disease in Nigeria: a cross sectional study. Pediatr Blood Cancer. 2015;62(7):1245-1251. doi:10.1002/ pbc. 25503

14. Fosdal MB, Wojner-Alexandrov AW. Events of hospitalization among children with sickle cell disease. J Pediatr Nurs. 2007;22 (4):342-346. doi:10.1016/j.pedn.2006.09.001

15. Panepinto JA, Brousseau DC, Hillery CA, Scott JP. Variation in hospitalizations and hospital length of stay in children with vasoocclusive crises in sickle cell disease. Pediatr Blood Cancer. 2005;44 (2):182-186. doi:10.1002/(ISSN)1545-5017 
16. Raphael JL, Mei M, Mueller BU, Giordano T. High resource hospitalizations among children with vaso-occlusive crises in sickle cell disease. Pediatr Blood Cancer. 2012;58(4):584-590. doi:10.1002/ pbc. 23282

17. Day S, Chismark E. The cognitive and academic impact of sickle cell disease. J Sch Nurs. 2006;22:330-335. doi:10.1177/1059840506022 0060401

18. Epping AS, Myrvik MP, Newby RF, Panepinto JA, Brandow AM, Scott JP. Academic attainment findings in children with sickle cell disease. J Sch Health. 2013;83:548-553. doi:10.1111/josh.12064

19. Cepeda ML, Allen FH, Cepeda NJ, Yang YM. Physical growth, sexual maturation, body image and sickle cell disease. J Natl Med Assoc. 2000;92:10-14.

20. Uganda Sickle Cell Rescue Foundation.Sickle cell stigma. Available from: http://www.uscrfuganda.org/. Accessed February 07, 2019.

21. Ola B, Coker R, Ani C. Stigmatising attitudes towards peers with sickle cell disease among secondary school students in Nigeria. Int $J$ Child Youth Fam Stud. 2013;4:391-402. doi:10.18357/ijcyfs44201312693

22. Kish L. Survey Sampling. New York: John Wiley and Sons; 1965.

23. Uganda Bureau of Statistics. The National Population and Housing Census 2014 - Area Specific Profile Series. Kampala, Uganda; Uganda Bureau of Statistics: 2017.

24. Musoke D, Boynton P, Butler C, Musoke M. Health seeking behaviour and challenges in utilising health facilities in Wakiso district, Uganda. Afr Health Sci. 2015;14(4):1046. doi:10.4314/ahs.v14i4.36
25. Uganda Bureau of Statistics. The National Population and Housing Census 2014 - Education in the Thematic Report Series. Kampala, Uganda; Uganda Bureau of Statistics: 2017.

26. Bazuaye GN, Olayemi EE. knowledge and attitude of senior secondary school students in benin City Nigeria to sickle cell disease. World $J$ Med Sci. 2009;4(1):46-49.

27. Bulgin D, Tanabe P, Jenerette C. Stigma of sickle cell disease: a systematic review. Issues Ment Health Nurs. 2018;39(8):675-686. doi: $10.1080 / 01612840.2018 .1443530$

28. Hopkins A, Hughes M. Individualized Health Care Plans. Young Exceptional Children. 2015;19(2):33-44. doi:10.1177/10962506145 66538

29. Sobze M, Tiotsia A, Djeunang Dongho G, et al. Youth awareness on sexually transmitted infections, HIV and AIDS in secondary schools in the Dschang Municipality (Cameroon): the mobile caravan project. J Public Health Africa. 2017;7:2. doi:10.4081/ jphia.2016.614

30. Merakou K, Kourea-Kremastinou J. Peer education in HIV prevention: an evaluation in schools. Eur J Public Health. 2006;16(2):128132. doi:10.1093/eurpub/cki162

31. Eisenstein C, Zamperoni V, Humphrey N, et al. Evaluating the peer education project in secondary schools. J Public Ment Health. 2019. doi:10.1108/JPMH-07-2018-0048
Adolescent Health, Medicine and Therapeutics

\section{Publish your work in this journal}

Adolescent Health, Medicine and Therapeutics is an international, peer-reviewed, open access journal focusing on health, pathology, and treatment issues specific to the adolescent age group. All aspects of health maintenance, preventative measures and disease treatment interventions are addressed within the journal and practitioners from

\section{Dovepress}

all disciplines are invited to submit their work as well as healthcare researchers and patient support groups. The manuscript management system is completely online and includes a very quick and fair peerreview system. Visit http://www.dovepress.com/testimonials.php to read real quotes from published authors. 